\title{
From Islamic Radicalism to Islamic Capitalism: The Promises and Predicaments of Turkish-Islamic Entrepreneurship in a Capitalist System (The Case of iGIAD)
}

\section{Ozlem Madi}

To cite this article: Ozlem Madi (2014) From Islamic Radicalism to Islamic Capitalism: The Promises and Predicaments of Turkish-Islamic Entrepreneurship in a Capitalist System (The Case of IGIAD), Middle Eastern Studies, 50:1, 144-161, DOI: 10.1080/00263206.2013.864280

To link to this article: http://dx.doi.org/10.1080/00263206.2013.864280

曲 Published online: 21 Jan 2014.

Submit your article to this journal $\sqsubset$

山 Article views: 464

Q View related articles ๘

View Crossmark data 5

Citing articles: 2 View citing articles $\square$ 


\title{
From Islamic Radicalism to Islamic Capitalism: The Promises and Predicaments of Turkish-Islamic Entrepreneurship in a Capitalist System (The Case of IGIAD)
}

\author{
OZLEM MADI*
}

'In the 1980s, we were trying to salvage our country; in the 1990s, we were trying to salvage our economy, and now we are trying to salvage our children.' This was the proclamation of Şükrü Alkan, President of the Islamic-oriented Association of Economic Entrepreneurship and Business Ethics (IGIAD), during a meeting last year in his Istanbul office. ${ }^{1}$ His statement succinctly captures our imagination about the predicaments, promises and concerns of a newly emerging Islamic bourgeoisie class. Focusing mainly on the members of IGIAD, the aim of this article is to demonstrate the incompatibility and contradictions between Islam and capitalism in contemporary Turkey.

Islamic economies play an increasingly prominent role in the global economy. Situating the Gulf within the evolution of capitalism at a global scale, Adam Hanieh argues that a new capitalist class, Khaleeji Capital, has profound implications for the Middle East as a whole. ${ }^{2}$ It is no exaggeration to say that the rise of Turkish Islamic capitalism, and with it an Islamic bourgeoisie and the accompanying lifestyle, have had profound implications for the Muslim world as well, since the Turkish Muslims have also been backed by a relatively successful democratic and liberal system that has allowed them to integrate more easily into the global system.

Much has been said on the evolution of the Turkish experience with Islam, capitalism and democracy; the phenomenon has shown that a unique Turkish blend of Islam, capitalism and democracy has been on the rise since the 1980s, an experience that reached its logical conclusion with the coming of the conservative and neoIslamist Justice and Development Party (JDP) to power in $2002 .{ }^{3}$ One of the significant outcomes of this politico-economic development has been the emergence of a new neo-Islamic bourgeoisie in Turkey. In the last three decades the members of this

*Political Science, Furman University, 3300 Poinsett Highway, Greenville, South Carolina, 29613, United States; Bilkent University, Political Science, Bilkent Universitesi, Ankara, 06800, Turkey.Email: ozlemmadi@hotmail.com; ozlem.sisman@furman.edu 
new class have found new 'opportunity spaces' in a Weberian sense in the Turkish economic-political context, ${ }^{4}$ and have emerged as a result of an ongoing negotiation between the self-perception of their Islamic identity and capitalistic world. As noted in a recent New York Times article, 'this religious merchant class, which sees nothing incompatible between wearing a head scarf and driving a Mercedes, is altering the society in a country once dominated by secular elite that banned the wearing of head scarves in public institutions'. ${ }^{5}$

But the story was not so simple for all the neo-Islamist rich Muslims. From the start, the burning questions for them were not only 'how to earn' but, more importantly, 'how to consume' within a capitalist system while still not transgressing Islamic boundaries. While riba', or usury, has been the biggest challenge in making money, israf or wasteful consumption has been the biggest challenge in their consumption. On the one hand, Muslims are exhorted to have social responsibility, an other-worldly orientation and high morality; on the other hand, competing within a market system, they are obliged to accept and adopt competitiveness, global integration, profit maximizing and the concerns of this world. Expectedly, living and acting in these two competing discourses causes a considerable amount of what I would call 'discursive tension' for practising Muslims. For many years, Muslim intellectuals (e.g. Sabahattin Zaim, Ersin Gürdoğan, Mustafa Özel, Hayrettin Karaman, Ahmet Tabakoğlu, Ali Bulaç and Mustafa İslamoğlu) as well as Islamic organizations (e.g. Milli Türk Talebe Birliği, Aydınlar Ocağı, Milli Görüş, MÜSİAD, Türkiye İşadamları ve Sanayicileri Konfederasyonu, Anadolu Aslanları İşadamları Derneği and IGIAD) have been either publicly or privately attempting to resolve these contradictions, and even creating an alternative Islamic economic system.

I argue that, over time, rather than creating an 'alternative Islamic economic system', Islamic actors have actually reduced - in some cases even eliminated - this discursive and ideological tension between Islam and capitalism by (a) trying to introduce Islamic morality into capitalism and, perhaps more importantly, (b) redefining both Islam and capitalism. Through these mechanisms they have both broadened and deepened Turkish modernity and capitalism. In this new context, economic rationality is represented as an Islamic value by the neo-Islamist actors who were able to create a new 'Islamic space' (or habitus in Bourdieu's sense) within the capitalist system. This new class formulates life and cognitive maps based on their ideas of Islamicizing market forces and engaging in neo-liberal practices within the modern world. As a result of this process this assemblage of Muslim nouveau riche have developed a whole spectrum of attitudes and approaches toward the capitalist system, stretching from a cautious, begrudging acceptance to almost a wholehearted adoption. These variations appear set to become increasingly capitalism-friendly in the next generation.

Of these Turkish actors, MÜSİAD (Müstakil İşadamları Derneği/Independent Industrialists and Businessmen Association) was the first organizational attempt to integrate Islam and capitalism. Although small in scale, IGIAD, a group which broke off from MÜSIAD, turned out to be a more ambitious institution than its progenitor in attempting to overcome the challenges that capitalism posed to Islam. By bringing the scholarly and business world together, they have been trying to create a theoretical framework and new 'opportunity spaces' in which wealthy Muslims could earn and spend in an Islamic way within a capitalist system. What is especially interesting about this avowedly Islamic association is that earlier, in the 1980s and 1990s, 
many of its members had been 'radical Islamists', opposed to the capitalist system altogether and considering the Turkish state to be un-Islamic and needing to be overthrown by Islamic revolution. Ironically, after having reduced the level of discursive tension between Islam and capitalism, these people have now become - with some reservations - the trailblazers of an 'Islamic capitalism' in Turkey. Their transformation fits very well into the main assumptions of the moderation theory. The theory, originally based on European socialist-Marxist and Christian democratic parties in the 1920s and 1930s, argues that radicals organized into electoral parties will most likely develop centrist and vote-maximizing platforms; and the parties will act moderately, especially under the threat of repression. ${ }^{6}$ Although the Turkish radical Muslims share certain characteristics with the larger neo-Islamist bourgeois class, which are more lenient in integrating themselves into the capitalist system, the IGIAD people are still very critical of conspicuous consumption. Unlike Erol Yarar, who was one of the founders and ex-presidents of MÜSIAD, ${ }^{7}$ they are still hesitant to call themselves a 'Muslim bourgeoisie' or 'Muslim Capitalists'. They rather call themselves 'rich Muslims'.

By examining the mission and activities of İGIAD, I aim to shed light on the ongoing discussion regarding the promise and predicaments of Islamic capitalism, as well as on various Islamist attitudes towards the capitalist system. Additionally, I hope, through this article, to contribute to the larger debates on the compatibility of Islam with capitalism and democracy. The IGIAD case is an instructive example that demonstrates the dynamic cooperation and interaction as well as the inherent tensions between Islam and capitalism in modern times. Unfortunately, there is as yet no single scholarly investigation on this young and ever-growing association. I believe that a better understanding of İGIAD will provide us with important insights, not only about the emergence of a neo-Islamic bourgeoisie class in Turkey, but, more generally, about what Vali Nasr terms the 'new Islamic middle class' in the Muslim world. ${ }^{8}$ This fact alone would seem to indicate that there is already a social division within the neo-Islamist class.

After a brief discussion about the economic and institutional developments that led to the birth of IGIAD, I will examine the neo-Islamic class struggle to reconcile Islam and capitalism within the Turkish context. Most of my data and insights are extrapolated from the IGIAD publications and from my in-depth interviews with 20 İGIAD members, six MÜSIAD members, and several other Muslim intellectuals and businessmen that I conducted between 2009 and 2011 for my doctoral dissertation. Since some of my interviewees did not want to be quoted directly, I have respected their wishes by not disclosing their full names in the footnotes.

Turkey's neo-Islamic bourgeoisie emerged as a result of a critical accumulation of, first of all, Islamic economic and political capital, and, subsequently, the formation of Islamic social and cultural capital over the past three decades. After the 1980 coup d'état and three-year military rule, Turkey experienced major shifts in the economic, political and social arenas. The emergence of Islamic economic capital took place especially in the 1980s and 1990s for three major reasons: a shift away from the country's traditional economic policy of import substitution industrialization, the state's changing policy on religion, and the emergence of Islamic financial institutions.

Turgut Özal, the first prime minister elected after the restoration of Turkish democracy in 1983, introduced new policies leading to the establishment of a free 
market system that increased the competitiveness of the Turkish products in the international market. The business owners who took the advantage of these policies were mainly conservative and tended to come from outside the ranks of Istanbul's traditional 'secular' industrialists, and were thus frequently referred to as the 'Anatolian Tigers' or as 'Calvinist Muslims'. International capital reorganized itself in Turkey through subcontracting agreements with local firms. The fragmented nature of production in the post-Fordist world allowed different parts of the same product to be produced in different countries. ${ }^{9}$ This global development provided a comparative advantage for the Islamic capital in Turkey and created new opportunity spaces for them. They were able to integrate more smoothly into the world capitalist system through sub-contracting agreements in labour-intensive industries like textiles and shoes and by taking advantage of the post-Fordist production system. ${ }^{10}$

In the meantime, interest-free Islamic banks and finance institutions were introduced at this time into the Turkish banking system. These institutions served in two ways in the process of Islamic economic capital accumulation. First, they attracted the savings of the religious Muslims who, due to the Islamic prohibitions on the charging of interest, did not use conventional banks. Through Islamic financial institutions these 'excluded' people were integrated into the system. Moreover, these institutions brought a significant influx of new funds to the system, as well as providing funds to Islamic business circles that had not heretofore used banks for capital loans, thereby further contributing to their development.

After the 1980 coup the military suppressed the individuals and groups espousing various leftist ideologies, but did not hesitate to use Islam as cement to keep together a society that was gravely divided along the ideological lines of the Cold War era. In its three years in power, the military junta even adopted a new state ideology that came to be known as 'Turkish Islamic Synthesis'. The use of this synthesis opened up new social and cultural opportunity spaces for the Islamic actors to present their identities. With the exception of the anti-systemic radical Muslims, most of the Islamists eventually became part of the political system, so much so that they started to win the local municipal elections from the early 1990s. The Islamist Welfare Party's (Refah Partisi) success in the mid-1990s and its major role in the 1996-97 Refah-Yol coalition government served as a milestone in the formation of Islamic political capital.

The coalition government was forced out of power by the Turkish military and secular establishment in what has become known as Turkey's first 'post-modern coup' on 28 February 1997, having been seen/suspected/accused by the country's secular powers-that-be of having advanced an Islamist agenda, and thereby violating the secular principles of the Republic. The 28th February Process left a very powerful impression on the Islamists, one that ultimately caused a change in the rhetoric and public perception of Islamists in both economic and political spheres. For example, the military's subsequently published list of 100 Islamic firms that were banned from government contracts caused the MÜSİAD members to emphasize the motto of 'money has no religion, no faith, and no ideology'. ${ }^{11}$

On the political front, the intervention persuaded the more pragmatic segment of the former Welfare Party to split off and form the Justice and Development Party (Adalet ve Kalkınma Partisi, AKP) immediately attracting the movement's more moderate factions and, in the process, steering political Islam closer toward 
the centre. The various clashes with Turkey's secular establishment and the series of party closures were part of a learning process for the country's Islamic actors, one in which they were forced to rethink and transform their assumptions about Islam and its relationship to the modern world. Islamic political actors realized that they needed to be in conformity with domestic and international powers in order to stay in power.

In the meantime, the accumulation of Islamist economic and political capital also accelerated the formation of their social and cultural capital. The new-found wealth of the previous decade was partially directed into scholarship, education, media and publishing houses with Islamist agendas. Urbanization, rising enrolment in higher education and growing links to the outer world contributed to the rise of a new class whose distinctive asset is their substantial human capital. The symbols of culture were reconfigured through Islamic media, educational institutions and the commodification of religion. Cultural capital became an important aspect of the neo-Islamic bourgeoisie that differentiated them from secular bourgeoisie and other lower Islamic classes. Now equipped with political and economic capital and embedded in capitalist culture, the neo-Islamic bourgeoisie attached more value to the means that facilitated this new bourgeois lifestyle. As a result of the accumulation of cultural capital, this class became more visible.

The victory of the Justice and Development Party in Turkey's 2002 national election marked a beginning of a new era of merging the Islamic economic, political, social and cultural capital into a new and effective synthesis.

Amidst all these developments, by the early 1990s Muslim entrepreneurs felt a need to have their own economic organizations. Rather than becoming members of the 'secularist' TÜSİAD (The Association for Turkish Industrialists and Businessmen/Türk Sanayi ve İşadamları Derneği), which was the largest Turkish economic union, its members holding almost 80 per cent of Turkish capital, these pious Muslims chose to establish their alternative and 'independent' economic association, MÜSİAD (The Association of Independent Industrialists and Businessmen). By 'independent', they meant both independent from traditional 'secular' Turkish capital, and from any specific Islamic group, Sufi order (tarikat) or community (cemaat). Shortly after its establishment, MǗSIAD quickly turned into one of the most important civil society actors in Turkey. MÜSİAD's collective organization of Islamic entrepreneurs constituted an important step for the development and spread of an Islamic economic discourse in Turkey. Their ambition was not only to create a new economic organization, but also a new economic man, homo Islamicus. ${ }^{12}$ Homo Islamicus is the idea of an Islamic entrepreneur that is simultaneously capitalist and equipped with Islamic morals and ethics. Homo Islamicus is the main actor in Islamic capitalism, but different from, and alternative to, the TÜSİAD's homo economicus. $\mathrm{He}$ is also different from the traditional pious Muslim businessmen as he is a 'capitalist', a profit-maximizing businessman. These new capitalists are loyal to religious values but open to change; they are progressive rather than traditional and - -most significantly - they are pragmatic. Economically speaking, they are 'rational actors,' making cost-benefit assessments to choose profitable areas for investment; they believe in competition - but within Islamic boundaries. As Şennur Özdemir has correctly pointed out, the MÜSIAD experience has greatly helped the transformation of the Anatolia-based conservative capital and deepened the Turkish 
modernity by bringing peripheral owners of capital into the centre and integrating them. $^{13}$

In the long run, however, the activities of MÜSIAD created discontent among some of its more pious members. It was this dissatisfaction that made the birth of İGİAD possible.

IGIAD was established as a splinter group of MÜSIAD in 2003. Although most of the IGIAD members are not openly critical of MÜSIAD, in the interviews I conducted it was possible to detect - if only between the lines - that they were not happy with the behaviour, morals and entrepreneurial styles of some MÜSİAD members and other rich Muslims. To them, MÜSIAD had grown too rapidly and thus uncontrollably (it currently has more than 3,000 members), something which caused it to stray from its original promises. Moreover, they claim, some MÜSIAD members have transgressed Islamic boundaries and immersed themselves too deeply in the capitalistic life style. With those criticisms in mind, eight businessmen and MÜSIAD members established the İGIAD after 'long and in-depth discussions', in the words of Şükrü Alkan.

Orhan Sağlam, one of the founders of IGİAD, thinks that one of the most important differences between MÜSIAD and IGIAD is that, while MÜSIAD is engaged in so many different national and international activities, IGIAD is specifically concerned with the raising up of a new Muslim entrepreneurial class that is engaged in personal and moral development. One of the ways of realizing this aim is to bring together businessmen and Muslim academics and scholars to create an ideal community. ${ }^{14}$ The AGU (minimum wage) policy, which requires each member employer to pay a prescribed level of salary to their employees (three times more than the regular minimum wage), is another important marker that differentiates IGIAD from MÜSIAD. ${ }^{15}$

IGIAD's primary aim is to place morality and ethics at the centre of all of their deeds. They prioritize being moral over being religious since religiosity is, after all, something between man and god. As moral individuals, they try to combine solidarity, social responsibility, other-worldly orientation and a high morality of Islamic ethics on one hand with economic competitiveness, global integration, profit making and this-worldly concerns on the other. Its purpose is not only to set an example for the business world, but also for family life and, by extension, for society at large. Needless to say, the model is near-utopian in its conception. In order to sustain the well-being of the community they have created a morality check mechanism by which every member could (and is supposed to) control and also advise his/her friends in their business. They have weekly seminars, book discussion groups and conferences aimed at increasing their knowledge and consciousness about how to live as good Muslims in a modern society. Activities by and for the young IGIAD members are there to ensure the moral well-being of the next generation. ${ }^{16}$

One of the most interesting characteristics of the early IGIAD members is that most of them were, in their own words, 'former radical Muslims'. Two or three decades back they refused to vote for any party - even those espousing the so-called National Outlook (Milli Görüş), the long-held ideology of Turkey's Islamists believing that voting would simply help to perpetuate an un-Islamic system. They also did not attend Friday prayers, thinking that they were living in a state of 'dar u'l-harb', a state in which Islam did not yet prevail. ${ }^{17}$ They refrained from membership in any Sufi order (tarikat) or Islamic cemaat, thinking that those hierarchic 
communities had been killing the 'individualism' and 'rationality' and putting the individual in a state of inactivity. They refused to pay taxes and shied away from any business with banks. They aspired to overthrow the system through a revolution, as in the case of Iran. This political background is one of the principal reasons for IGIAD currently possessing a more rigid and disciplined structure than that of MÜSİAD. Through reducing the ideological tensions between their own self-perception and the capitalist system in which they lived, they were eventually able to become significant new players in this system, albeit with some reservations. The inclusion of yet another oppositional front in the system, one could argue, helped to both broaden and deepen Turkish modernity.

Today, the organization has almost 200 members, most of whom are Anatolianbased Islamic businessmen. Some 40 per cent of them also still retain membership in MÜSIAD. Similar to the case in most other Islamic organizations, women are underrepresented in İGIAD, with only one female member. When I asked my interview subjects about the reason for this great gender disparity, all of them - including the woman member, Sema Geçimli, an information techonology expert - told me that there were not many businesswomen who met the criteria for membership. ${ }^{18}$

IGIAD's religious character resembles a mosaic, comprising members of various Islamic groups, including Fethullah Gülen's cemaat. The average age of its members is 40-50, and most were of Eastern Anatolian - and predominantly Erzincan - origin. They are predominantly the children of first-generation migrant families, mostly to Istanbul. The majority received their higher education in the prestigious schools of Turkey's major cities, such as Ankara and Istanbul. Like the early founders of MÜsIAD, many of the İGIAD founders were graduates of Bosphorus (Boğaziçi) University, the beacon of bilingual and western education in the 1980s and 1990s.

The headquarters of IGIAD is in Istanbul. Alkan stated that there has been a growing demand from Anatolia (mainly from cities closer to Istanbul like Bursa or Izmit) to open up new branches of IGIAD, but they were not ready for such a move. The low membership numbers are due to the organization's strict criteria for membership. Somewhat akin to the Masonic membership process, members are not a self-selecting group, but people who have been recommended by at least two existing members. In order to maintain a controlled and sustainable growth, they have an advisory board, a mix of businessmen and academics. Of the 25 members of the Board, 13 are academics, such as Ahmet Tabakoğlu, Cengiz Kallek, Ersin Gürdoğan, İbrahim Öztürk, Mustafa Özel and Nihat Erdoğmuş. One of the most important IGIAD activities is their publication of the biannual Turkish Journal of Business Ethics, which shows the organization's ambition of combining academic and business knowledge for the purpose of creating a model for an 'Islamic economy'. In the words of some of the members, they want to be remembered and associated with business ethics 15-20 years from now. These activities ensure that an IGIAD member 'does business in accordance with the market economy, but also in accordance with moral principles. An İGIAD member avoids being only a market man'. ${ }^{19}$

How is it possible to avoid being a market man? This has been a question that has vexed pious Muslims for decades. How should a Muslim engage in a modern capitalistic world? Capitalism provides Muslims with opportunities for economic growth and wealth, while simultaneously offering ways in which to consume that newly acquired wealth. As the material gain for the capitalist world increases, new Muslim 
consumers find themselves stuck between capitalistic consumerism and Islamic moral values. On the one hand, Islamic wealth should also come with social responsibility, an other-worldly orientation and high morality; on the other hand, Muslim businessmen are also obliged to adopt the practices of competitiveness, global integration, profit maximizing and the concerns of this world. Living and acting in these two competing discourses causes 'discursive tension' for the Muslims.

In principle, Islam strongly encourages Muslims to engage in business. The Prophet is reported to have said: 'Be Involved in trade/commerce (ticaret), since nine tenth of one's livelihood (rizik) is trade/commerce and [courage]!' ${ }^{20}$ Business is not only seen by Islam as an acceptable pursuit, but even as a dignified activity. Muslim entrepreneurs are seen as vice-regents of God (halife), and have the responsibility to increase prosperity because business is considered to be a component of the good deeds to be performed in the search for Allah's blessings. Gaining profit is one of the important motivations for doing business but, in contrast to the Calvinist Protestant model, material success should not be considered proof that one is standing in the favour of God. What is important in fact is not what you gain but what you do with it once you've got it. A Muslim businessman is to make profit not for the sake of becoming wealthier, but for the betterment of the community (ümmet). Islam is not against private property ownership. However, God is the absolute owner of wealth and has created wealth in abundance and sufficient for all. ${ }^{21}$ Wealth is only entrusted to mankind. So even the profit-maximizing entrepreneur is not the ultimate owner of the wealth, but the keeper of Allah's wealth. The religion has its own inner mechanisms, such as the mandatory 2.5 per cent charity tax incumbent upon all Muslims (zekat), for the redistribution of wealth.

IGIAD, in its mission statement, clearly expresses that it places 'justice' or 'God' $(H a k)$ at the centre of its activities. Alkan notes that the foundation of the ethic for IGIAD is Islamic morality. To him, although there is no modern and systematic Islamic economic theory, Islam gave us some parameters in which the terms such as 'good deeds' (hayir), 'blessing' (bereket), 'livelihood' (rizik), 'waste' (israf), 'thrift' (tasarruf), 'charity' (infak), 'charity' (tasadduk), 'permissible' (helal), 'forbidden' (haram), 'modesty' (itidal) and 'conspicuous consumption' (gösteriş) can help us to construct 'Do's and don'ts' for our lives. ${ }^{22}$ Sağlam qualifies the term 'ethic' even further and says that the ultimate criteria for Muslims are the Quran, Sunnah and the practices (sünnet) of the Prophet and of his companions. ${ }^{23}$ In its own vocabulary, as stated in its mission statement, 'IGIAD does not accept non-ethical market conditions; it works towards the establishment of a Hak-centered business life; and encourages a halal division of profit'. ${ }^{24}$

With these Islamic principles in mind, devout Turkish Muslims have ventured into business within the capitalistic system. Recognizing the challenges of a top-down system change, they revised some of their assumptions about both Islam and capitalism. Many of them began to think that Islam and capitalism shared many commonalities, if not necessarily on the matter of morality. The biggest missing element in capitalism is the lack of morality, which was to be grounded in religion. By reintroducing morality into capitalism, they reasoned, it was possible to Islamicize or tame 'wild' capitalism and turn it into a 'merciful capitalism'. By examining redefinition of Islamic concepts of riba (usury, interest) and israf (wasteful consumption), now I would like to show how the Muslims reduced the discursive tension between capitalism and 
Islam. While riba is an important concept related to the earning of money, israf is an important one for spending it.

Almost all the Muslim scholars agree that Islam prohibits any transaction that involves riba, i.e. usury or interest. Making money out of money without making any investment and taking any risk of that investment is not permissible. As quoted in one of the IGIAD publications, the Prophet Muhammad is said to have damned all of those who dealt with riba. ${ }^{25}$ Modern capitalism and the banking system, however, are based on interest-generating mechanisms. A pious Muslim, therefore, is supposed to avoid any transaction with conventional capitalist banks. But how then is s/ he supposed to conduct business outside of the global economic system? This challenge has led to the rise of interest-free banking systems, first introduced in the Gulf countries, and then in other Islamic countries in the 1970s. In 1983, the Özal government allowed the establishment of Islamic financial institutions in Turkey as well. Since then, these institutions have been developing in Turkey. As Mustafa Dereci, Retail Banking Product Development Manager of Kuveyt Turk, states, the Islamic banks are anticipating a 10-14 per cent share of the national asset in five years. ${ }^{26}$

The main idea of Islamic banking is to replace interest by profit- and loss-sharing contracts. But many sceptics claim it is almost impossible to work completely outside of the interest-based global economic system. Still, they carefully differentiate the Quranic riba, which is absolutely haram, and other forms of interest-generating investments. Reflecting the last three decades of debates on the issue, Hayrettin Karaman, one of the most respected Islamic scholars in neo-Islamist circles and a frequent member of the 'advisory boards' of many Islamic banks and organizations (including the Albaraka Türk and Kuveyt Türk banks, ${ }^{27}$ issued a ruling (fetva) stating that doing business with an interest rate below or at the inflation rate was not haram since it is not earning money out of money, but protecting the rights of the money lenders. ${ }^{28}$ In the long run, such interpretations allowed some Muslims to do business with the conventional banks in Turkey.

Although Mustafa İslamoğlu, the most revered Islamic scholar in the İGIAD circle, strongly recommends using the Islamic banks ${ }^{29}$ some IGIAD members deem it necessary to work with conventional banks as well. Alkan thinks that the best way to avoid the dangers of doing business in the capitalist world is to have a 'Fatwa Board', consisting of Muslim academics and scholars. This board would help businessmen in questionable matters regarding which they could not decide on their own. ${ }^{30}$ To some sceptics, such as Nihat A., acquiring a fatwa is just a way of clearing the conscience, but it does not necessarily render the economic transactions in question more Islamic. ${ }^{31}$ Other sceptics, such as Erol Yarar and Mustafa Y., think that most Muslim scholars do not really know or understand the modern business world and thus their opinions are often detached from reality.

As the volume of neo-Muslim capital and international business grew, many of these Muslim businessmen found that the conventional banks were more efficient than the interest-free ones. Several of my interviewees told me that the Islamic banks were still very small and inefficient when it came to the overseas transactions, and that is why they were forced to work with major conventional banks. Some of them said that they use the conventional banks only for money transfers but not for investment, since the latter could accrue interest. If they earn money from interest, they say, they donate it to charity. 
The so-called 'Market of Medina' is another tool to ease the discursive tension between capitalism and Islam. To the new Islamic bourgeoisie, the 'Market of Medina' constitutes a basis for Islamic economy and capitalism. ${ }^{32}$ The 'Market of Medina' was established by the Prophet Muhammad himself in the formative stage of Islam and it serves as the ideal model for an 'Islamic free market'. The model could even be likened to Adam Smith's 'invisible hand'. The market has non-interventionist characteristics and is tax-free. Prices are determined by market forces. In this system the motto is 'sanctified wealth' - in essence, wealth earned according to Islamic market principles. ${ }^{33}$ Although the market is left to its own devices, there is always a 'moral filter' to minimize unnecessary claims on resources. In this model both the Muslim buyer and seller should have mercy towards each other. ${ }^{34}$ To prove the compatibility of Islam and capitalism, it has become a tool for legitimizing their demands for adaptation of neoliberal policies. In one of my interviews, Osman A. said:

In fact, it was our religion and Prophet Muhammad who instituted the idea of free trade many centuries before the West came up with the idea of free market. Later, with the demise of the Islamic empires and the coming of imperialism, they made us forget our own values. The Market of Medina is one of our own values. $^{35}$

These kinds of reinterpretations and re-appropriations of old Islamic concepts have been one of the factors making Muslims more comfortable with engaging in the capitalistic system, and are found even among the IGIAD members. Nevertheless, it is important to note that there are also some IGIAD members who prefer 'not to do business with the state, even if JDP is in power, since corruption and bribery are still part of doing business with the state':

Doing business is a kind of mission for us. Nevertheless, we should not cross red lines while doing business. For that reason, although we are in construction business and have organic relationship with the JDP, we prefer not to conduct business with the municipality or with the state. ${ }^{36}$

Another member stated the same concern, using bolder reasoning: 'Although the JDP is in power, the system is still an interest-based system. We do not want to pollute our earnings with the interest-ridden business. ${ }^{37}$ And yet another member complained: 'The state posts are being distributed not according to merit but according to loyalty to the JDP. Nobody can deny the positive developments under the JDP regime; however there is still a long way to go for Muslims. ${ }^{38}$

Starting from the late 1990s, consumerism became a grave challenge to Islamic bourgeoisie. This challenge was far more recent than that of interest, and in many ways more serious. The sudden accumulation of great financial capital by the Anatolian tigers brought with it the opportunity to experience new lifestyles that were quite different from the traditional Islamic ones. This new class did not acquire its power exclusively by owning the means of production in a Marxist sense, but also from political and cultural capital in Bourdieu's meaning. A new identity was formed around new consumption patterns, relations to means of production and evolving interpretation of religion. The new bourgeoisie also attained a Weberian type of 
social status with its new fashion of veiling, five-star vacationing, prestigious cars and palatial houses. The increased economic capital, combined with rising social capital, led to the opening up of new opportunities for the Islamic bourgeoisie. New Islamic media outlets, such as TVs, newspapers and journals became the primary means of advertising for Islamic commodities. Products like Islamic dolls, Islamic soft drinks and Islamic garments helped the neo-Islamists to define themselves with their own distinct identity.

While the first generation earned money and mostly invested it rather than consuming it, the next generation earned money and did not hesitate to consume conspicuously. ${ }^{39}$ While the earlier generation considered some of the consumption as israf (wasteful consumption), the new generation chose to view it as ihtiyaç (need). In the minds of traditional Muslims, israf is simply haram. ${ }^{40}$ On a discursive level, while the ideal role model for the old generation was Abu Dharr al-Ghifari, one of the poorest and most pious companions of the Prophet Muhammad, the ideal role model for the new generation became Abu Bakr, one of the Prophet's wealthiest companions.

What are the boundaries between permissible and wasteful consumption in Islam? The answer to this question has changed over time as Turkey's Muslim bourgeoisie has attained more material wealth, becoming broader and more flexible to accommodate the demands of the Islamist bourgeoisie. In the new interpretation a Muslim has the right to consume whatever he/she needs as long as it does not violate any Islamic principles, since Muslims, as those following God's precepts most closely, deserve the best of everything. In the new capitalist Islam the difference between need and luxury is eliminated and capitalist consumerism dictates luxury as need. Consumption then becomes a symbolic capital. In the new mindset, there was nothing wrong with being wealthy as long as it was earned in halal ways. As another influential Muslim intellectual proclaims 'Muslims should consume as much as they need, according to the living standards of his social community'. ${ }^{41}$ Thus the definition of 'need' changes in accordance with the community. Here, too, the IGIAD members have been a bit more careful to keep the boundaries of lawful consumption narrower. To Hamit Y. for example, israf means spending money on things that do not have any return on them (geri dönüşü olmayan şey israfttr).

When I raised the question of the definition of israf with one of the founding members of IGIAD, he responded as follows:

Property is God's trust (emanet) to us. We have to use it carefully. Israf is not using the property in accordance with its function. The limit of israf is not determined by the holy book, but by societal norms and values. You cannot find any source to condemn driving an SUV. In order to produce more, you need to spend more. ${ }^{42}$

Another interviewee, however, was of the opinion that consumption was acceptable as long as one stayed within the Islamic boundaries: 'Even Muhammad was riding the most expensive camels. He did not show off or engage in conspicuous consumption. Muslims have the right to consume high quality products. ${ }^{, 43}$

In my interviews with MÜSİAD members, most offered reasons to legitimize their luxurious houses, cars, expensive watches and skiing holidays. Unlike many other wealthy Muslims, İGIAD members seemed to live a more puritanical and modest 
life. During my interviews, I have not seen any business office, for example, which was decorated with luxurious and stylish furniture, paintings or carpets. In the words of the chairman:

As IGIAD, we should represent an example to other Muslims by observing the permissible (halal) and the forbidden (haram). As Muslims, we should always remember that our faith differentiates us from other people. We should develop an inner check mechanism by which every Muslim should check each other and warn the ones who engage in this-worldly affairs more than necessary. Even the Caliph Omar would ask the Companion Huzeyfe every day whether he saw in him any signs of hypocrisy. ${ }^{44}$

The sceptics, such as Mehmet Y. and Nihat A., think that as the IGIAD gets older and bigger, it will eventually turn into a MÜSIAD-like organization. ${ }^{45}$ The consumption patterns of neo-Islamists have begun to create a social division between this new class and other Islamists, and are a result of the encounter of Islam with the global forces of consumerism and neo-liberal capitalist market forces. This differentiation creates a conflicting class consciousness within the new class as well. In one of the interviews, an IGIAD member stated:

There is a growing class-consciousness among the wealthier Muslims in Turkey. This is a natural consequence of earning money. Now Muslims are living in gated communities, having iftars at five star hotels, and going on very expensive vacations. I am not so worried about myself, as I both know what it is like to be poor and to be wealthy, but my children have been born into wealth. They do not know what it is like to live in a poor neighborhood, not to have a car, and to have nothing for holidays. I am very much worried that Muslims may lose the consciousness of ummah, if they do not do something about the next generation. ${ }^{46}$

Veiling and fashion are other interesting areas for demonstrating the changing definition of consumption patterns for Muslims and critiques of it. At the end of the 1990s there were very few companies producing specifically for observant Muslim clients. Starting from the 2000s, however, one can observe a more stylistic understanding of fashion in Islamic women's garments. Looking at the Islamic fashion shows, for example, one can easily see an eclectic style taken from Indian, Arabic and European modes. For example, a European-style wedding dress merged with a veil and decorated in Arabic style. ${ }^{47}$ They merge the western types of clothing with Islamic ones. Fashionable Muslim women can be seen wearing the latest jeans, jackets, dresses and tops, signalling their familiarity with fashion. There are two features that distinguish the new bourgeois women from the lower class devout Muslims and secular women. The brands of the garments and fashionable outfits differentiate this segment from the lower classes in the social hierarchy. The new 'Islamic woman' wishes to dress both Islamically and fashionably, making for a particular manner of merging the local with the transnational. In this regard, we see a 'fashionizing' of the veil; whereas only a generation ago it was a symbol not only of piety and Islamic religious observance, but of political and cultural affiliation in Turkey, it is today merely a statement of fashion and social status. A New York Times article notes the success of 
the Muslim magazine Ala, which has been called the 'Vogue of the veiled' in the Turkish news media. At the time that the article was written, it had attracted 30,000 subscribers since its founding in June 2011, which reflects the rise of a Turkish Islamic bourgeoisie and its growing consciousness of fashion and status. There are İGIAD members and also other Muslim intellectuals, such as Ali Bulaç, Ayşe Böhürler and İhsan Eliaçık who have denounced Ala for championing what they call a crass commercialism at odds with Islam. ${ }^{48}$

The reconfiguration of space and class can also be observed in the new bourgeoisie's preference for expensive and ornate Ottoman-style furniture and decoration in their gated communities, in their enjoyment of summer vacation at 'turban hotels' (Alcohol-free hotels that offer more Islamic-oriented entertainment, such as whirling dervish shows) and in their fulfilment of their Islamic duty of Hajj in five star hotels overlooking the Kaaba in Mecca. Through these practices the Islamic bourgeoisie mix Islam with capitalism and are creating a new Islamic lifestyle dominated by pragmatism and leisure time.

Parallel to the aforementioned developments, the very conception of capitalism has also been in transformation in the minds of Muslims. The terms capitalism and capitalist system had always held negative connotations for Turkey's Islamists and Leftists, albeit for different reasons. For the Left, borrowing heavily from Marxist terminology, capitalism denotes the existence of a bourgeoisie class, owners of the means of production who exploit the lower classes. For the Right - and for the Islamists in particular - the term signifies the West in general, and with it a value system that is seen to contaminate and corrupt the Turkish and/or Islamic world through the projection of hard and soft power. For radical Islamic actors, who were heavily influenced by the Iranian Revolution and the writings of Sayyid Qutb of Egypt, Ali Sheriati of Iran and Mewlana Mawdudi of Pakistan, capitalism and the capitalist system have been widely denounced since the 1980s. As is clearly reflected in the words of one of the Turkish radical Muslims, they were after changing the capitalist system entirely:

In my university years I was not voting for the Welfare Party as if it was another system party. We were quite inspired by the 1979 Iranian Revolution and wanted to replace the secular state system with an Islamic one. Only later we learned that it was impossible to capture the state mechanism. ${ }^{49}$

As Özdemir showed in the MÜSİAD context, Islamic businessmen were initially hesitant to even define themselves as businessmen, in order not be associated with the capitalist system. ${ }^{50}$ However, beginning in the 1990 s, the term capitalism freed itself from negative connotations as Turkey witnessed the emergence of an Islamic bourgeoisie class that was forming a new identity through new public spaces and lifestyles.

Starting in the 1990s, the demands of the new bourgeoisie for neoliberal policies and democratization weakened the support for radical Islamists and pulled the country's political Islam closer to the political middle. As they increasingly became the winners within the existing system, rather than destroying it they preferred to transform it by incorporating their values into it. Now they are "playing the game with the tools of the enemy'. ${ }^{51}$ The new articulation of capitalism and weakening of 
radical Islam could be best seen through the former radical Muslim members of IGIAD, Hamit Y., who defines capitalism as an 'ego-centred, unlimited ambition for growth'. ${ }^{52}$ Likewise Halim O. defines it as 'ultimate egotistical exploitations of others'. But capitalism with human values is different:

It is now impossible to ignore capitalism. We have realized that we could not destroy this system. Rather than destroying it, we would like to control it; tame it through injection of Islamic norms and principles. The rejection of capitalism has two main causes. First, the puritanical 'living on very little' (bir lokma bir hirka) philosophy that denies the possibility of a rich Muslim, and the second, the people who do not know how to cope with it. But we do know how to cope with it: [we have therefore created a] capitalism that is balanced by Islam. ${ }^{53}$

To people like Erol Yarar the philosophy of 'living on very little' has been like opium to put the Muslims asleep for many centuries. ${ }^{54}$ In this context, the former elites, especially member of TÜSIAD, are accused of imposing their secular ideology and capitalist lifestyle on the masses:

Due to the lack of morality in previous wealthier segments of the society, people associated capitalism with lack of morality, and all other negative connotations. But now everybody sees we can incorporate our cultural and religious values to capitalism and still earn money. ${ }^{55}$

And yet another member offered an implicit criticism of TÜSİAD, claiming that they were protected by the state unfairly and that was the reason for the economic crisis in Turkey in recent decades.

Competition is the key. However, it should be 'just', and prioritize the 'dignity of the human being'. As businessmen, we need a free market without the intervention of the state. The previous economic crises in Turkey were closely linked to the state policies and the state's protection over certain segments of businessmen. Today we have a more just and free market system. ${ }^{56}$

When capitalism is augmented with a 'human touch', the newly wealthy no longer hesitate to define themselves as Muslim capitalists. Some IGIAD members are even more lenient in their use of the term. Mehmet K., who is a member of both MÜSİAD and IGIAD, mentions the impossibility of working completely outside of the capitalist system. In order to ease the tension between Islam and capitalism he claims that Islam is highly adaptable to new systems. After all, he says, 'all sins are for Muslims. We would commit a grave error, if we claim that they were not sins when we committed them'. ${ }^{57}$ This approach, in a way, takes away the burden of sinning from the believer, and let him/her engage in the capitalist life. One other factor that helped the change in conceptualization of capitalism was a loss of belief in the possibility of creating a full-fledged 'Islamic economic system'.

Islamic economics does not exist. Islamic economics does not have its own peculiar ideology. You cannot find any systematic work that is solely written on 
Islamic economics. Islamic economics is too vague, its rules are not determined so it cannot replace capitalism as a system. ${ }^{58}$

And yet another factor that has legitimized the process of Islamifying the economic system was the continuous boom-bust cycles of capitalism that create global economic crises. The new Islamic bourgeoisie class feels the need to add Islamic ethical values to the existing Weberian 'Rational capitalism' as it would fulfil the needs of the pious businessmen. Moreover, there is a great chance of this new 'Islamic capitalism' being adopted as a model in the international arena. Many of the interviewees blamed 'wild' capitalism, operating solely on interest-generating mechanisms, for the global economic crisis in recent years. To them, an 'Islamic capitalism' could save the world from global economic crisis. As Özdemir suggests, if Weber is right in claiming that the salvation from the 'iron cage' is dependent upon emergence of a new 'charisma' or emergence of new ideals, then filling materialist capitalism with Islamic principles that emphasize 'the priority of human' could be an exit from that cage. ${ }^{59}$

As seen from various examples, capitalism and Islam have transformed and even invigorated each other within the Turkish context. Wealthy Turkish Muslims have striven hard to arrive at this point. The new bourgeoisie's transformation has three important dimensions in Turkey. The first is the post-1980 neo-liberal policies and shift to an export-led growth model, which enabled the embourgoisement of conservative small businesses by integrating them into global markets. However, contrary to 'Muslim Lutheran' or 'Muslim Protestant' arguments, rather than choosing an ascetic life in the Weberian sense, the new Muslim bourgeoisie have internalized the surrounding capitalist culture. This is quite visible in their consumption patterns and in the newly created 'Islamic' public spaces. The second dimension is the merger of 'Islamic' financial, social and political capital, in Bourdieu's meaning. And the third dimension is the reconciliation of Islam with capitalism.

The members of this class were anti-western and anti-capitalist in the 1980s and the early 1990s, trying to create an alternative Islamic economic model. Rather than creating an alternative model, however, they were integrated into the capitalist system, by introducing Islamic and moral values into the economic system. Over time they also redefined their own identities and the very notion of capitalism itself. The forces of capitalism triggered a process in which Islamic identities were reformulated to the extent that even the most radical and puritan Muslims have redefined their Islamic values, norms and ethics. The new Islamic bourgeoisie took the lead in this reformulation.

Despite their integration into the system, the new bourgeoisie differed from the secular 'Republican bourgeoisie' as well as from traditional devout Muslims. Unlike the secular elite, they are capitalists with moral values, and unlike the traditional Muslims, they are Muslims with capitalist values.

As the members of the new wealthy Islamic class were integrated into the capitalist system, the tension and criticism within the Islamic intellectual and business communities intensified. The emerging wealth led to stratification within the Islamic community, thereby bringing further tensions. The paramount criticism, coming especially from within Islamic circles, was not about the new methods of doing business or earning money within the capitalist system; rather, it was on the conspicuous spending of that money. 
The integration of Islamic values into a capitalist economy has not been an easy task. As one of the IGIAD members states, 'You have to have an economic power which is also supported by intellectual paradigms. We have some difficulties in the capitalist secular world both in economic and also cultural social life. We need intellectual leaders to show the ways to the Muslim entrepreneurs and give advice (fatwa) in the matters that we need help' ${ }^{60}$

For the IGIAD members the Islamization of capitalism is a twofold task: on one hand, you need to have economic capital and an entrepreneurial class that will supply and sustain this capital; on the other hand, there is also need for intellectual capital that will serve as a check against the possibility of 'losing one's way' in the capitalist world. Most of the İGIAD members I interviewed mentioned that at least some of the pious Muslims are losing the 'battle' against materialization. All pointed to the need to have an inner check mechanism, which, they believe, would help them remain within the 'Islamic' circle.

In sum, İĠAD constitutes a unique group of people in this newly emerging Islamic bourgeoisie class. They are the most conscious in addressing challenges and criticisms. They strongly believe that they have a capacity to overcome ensuing challenges, as reflected in the words of Orhan Sağlam, 'Islam is not a difficult and complex religion to live by after all'. ${ }^{61}$ The story is still unfolding.

Given the new Turkey's increasing interaction with the Muslim world on the political, economic and cultural levels, I believe that the experience of Turkish capitalism (and democracy) and its discontents will be ever more relevant for newly rising conservative and liberal middle and upper classes throughout the Muslim world.

\section{Notes}

would like to thank all of my interviewees, especially Şükrü Alkan, who generously found time for me in their busy schedules and shared sincere thoughts on their professional and personal issues. I also owe thanks to Metin Heper, Ergun Özbudun, İhsan Dağı, Mahmoud Ayoub, Akan Malici, Cengiz Sisman and Paul Bessemer, who read the draft of the article and made valuable comments to enrich it.

1. Interview with Sükrü Alkan, 15 June 2010.

2. A. Hanieh, Capitalism and Class in the Gulf Arab States (London: Palgrave Macmillan, 2011).

3. For some examples see M. Heper and Ș. Toktaş, 'Islam, Modernity and Democracy in Contemporary Turkey: The Case of Recep Tayyip Erdoğan', The Muslim World, Vol.93, No.2 (April 2003), pp.157-85; E. Özbudun and W. Hale, Islamism, Democracy and Liberalism in Turkey: The Case of the AKP (London: Routledge, 2009); I. Dağı, 'Turkey's AKP in Power', Journal of Democracy, Vol.19, No.3 (July 2008), pp.25-30; N. Göle and A. Ludwig, Islam in Public (Istanbul: İstanbul Bilgi Üniversitesi, 2006); J. White, Islamist Mobilization in Turkey: A Study in Vernacular Politics (Washington, DC: University of Washington Press, 2002); H. Yavuz, Islamic Activism: A Social Movement Theory Approach (Bloomington: Indiana University Press, 2010); H. Yavuz, Islamic Political Identity in Turkey (Oxford: Oxford University Press, 2003); T. Kuran, The Long Divergence: How Islamic Law Held Back the Middle East (Princeton, NJ: Princeton University Press, 2011); Z. Öniş, The Emergence of a New Turkey: Democracy and the AK Party (Salt Lake City, UT: University of Utah Press, 2006). For a general discussion on Islam and Capitalism, see C. Tripp, Islam and the Moral Economy: The Challenge to Capitalism (Cambridge: Cambridge University Press, 2006), and M. Çizakça, Islamic Capitalism and Finance: Origins, Evolution and the Future (Northampton, MA: Edward Elgar, 2011).

4. As Hakan Yavuz defines 'opportunity spaces' as mechanisms that include independent newspapers, periodicals, radio stations, TV channels along with financial institutions, private education facilities, 
Islamic tesettur hotels as well as consumption, social interactions shared meanings and associational life. See his Islamic Activism: A Social Movement Theory Approach, p. 272.

5. D. Bilefsky, 'A Fashion Magazine Un-shy About Baring a Bit of Piety', New York Times, 29 March 2012.

6. For a successful implementation of the moderation theory in the Middle Eastern context, see G. Murat Tezcür, Muslim Reformers in Iran and Turkey: The Paradox of Moderation (Austin: University of Texas Press, 2010).

7. Interview with Erol Yarar, 20 July 2009.

8. V. Nasr, Forces of Fortune: The Rise of the New Muslim Middle Class and What It Will Mean for our World (New York: Free Press, 2009).

9. A. Ökten, 'Post-Fordist Work, Political Islam and Women in Turkey', Middle East Economics, No.4 (2001), pp.269-88.

10. A. Buğra, State and Business in Modern Turkey: A Comparative Study (Albany, NY: SUNY Press, 1994), p.25.

11. A. Buğra, 'Class, Culture, and State: An Analysis of Interest Representation by Two Turkish Business Associations', International Journal of Middle East Studies, Vol.30, No.4 (1998), pp.521-39.

12. See the MÜSIAD website: http://www.musiad.org.tr/detayArYay.aspx?id = 157 (accessed 26 March 2012).

13. Ş. Özdemir, MÜSİAD: Anadolu Sermayesinin Dönüşümü ve Türk Modernleşmesinin Derinleşmesi (Ankara: Vadi Yayinlari, 2006), pp.243-55.

14. Interview with Orhan Sağlam, 24 Aug. 2010.

15. AGU Report (Istanbul: IGIAD Publications, 2008).

16. The organization is keen on preparing the next generation for the business world. N. Erdogmus, Aile Işletmeleri: Yönetim Devri ve İkinci Kuşă̆ın Yetiştirilmesi (Istanbul: İGİAD, 2008).

17. According to a well-established Islamic tradition, if a country is considered 'daru'l-harb', this country is an un-Islamic one, and a Muslim is not supposed to go the Friday prayers, until the country becomes Islamic.

18. Interview with Sema Geçimli, 4 Jan. 2011.

19. Interview with Alkan.

20. Although there are some debates about the authenticity of this Prophetic tradition, or hadith, those debates are beyond the scope of this chapter. What is important is the fact that the hadith is widely known and quoted by many Muslims - including wealthy ones.

21. A. Rauf, Economics of an Islamic Economy (Leiden: Boston, 2010).

22. Interview with Alkan,

23. Interview with Sağlam.

24. See IGIAD website, http://www.igiad.com/?lang $=$ tr\&s $=329 \& s s=332$.

25. Z. Güler, 40 Hadiste Iss ve Ticaret Ahlakı (Istanbul: İGİD, 2010), p.134.

26. An interview with Mustafa Dereci, 10 July 2010.

27. Since having a High Fatwa Board is prohibited by law in Turkey, many Islamic financial and business institutions and organizations have formed 'advisory boards' to ask for fatwas in economic matters.

28. H. Karaman, 'Enflasyon ve Faiz' [Inflation and Interest], Yeni Şafak, 10 Sept. 2010.

29. See his lectures on economic issues such as riba, banking, and credit loans on his own website, http:// www.mustafaislamoglu.com/651_Faiz.html (accessed on 1 April 2012).

30. Interview with Alkan.

31. Intereview with Nihat A., who is a MÜSIAD member, 20 Dec. 2010.

32. For example, when he is explaining the model for the MÜSİAD Fair (held 6-10 Oct. 2010), the General Manager of MÜSIAD, Ömer Cihad Vardan, stated that the Fair was modelled after the Medina Market.

33. B. Gokarisel and A. Secor, 'New Transnational Geographies of Islamism, Capitalism and Subjectivity: The Veiling Fashion Industry in Turkey', in J. Pink (ed.), Muslim Societies in the Age of Consumption (Newcastle: Cambridge Scholars Publishing, 2009), pp.23-53.

34. U. Chapra, Islam and Economic Challenge (Leicester: Islamic Foundation, 1992).

35. Interview with Osman A., who is a MÜSIAD member, 2 Jan. 2011.

36. Interview with Hüseyin D., 30 Dec. 2010.

37. Interview with Mustafa Y., 7 Jan. 2011.

38. Interview with Ali G., 5 Jan. 2011. 
39. Thorstein Veblen uses the term to depict the behavioural characteristic of the nouveau riche, a class emerging in the nineteenth century as a result of the accumulation of wealth during the Second Industrial Revolution. See T. Veblen, The Theory of the Leisure Class (London: Penguin Books, 1994).

40. The Quran contains several verses about the israf. For instance: 'Children of Adam take your adornment at every place of prayer. Eat and drink, and do not waste. He does not love the wasteful'; 'We have destroyed the wasteful' (Enbiya 9). Still however, the definition of israf differs from scholar to scholar.

41. S. Zaim, Ekonomik Hayatta Müslüman Insanin Tutum ve Davranışları (Istanbul: MÜSİAD Yayinlari, 1994), p.106.

42. Interview with Ömer O., 21 May 2010.

43. Interview with Hüseyin A., 17 Dec. 2010.

44. Interview with Alkan.

45. Interview with Mehmet Y., 26 Dec. 2010.

46. Interview with Mehmet C., 20 July 2010.

47. Gokarisel and Secor, 'New Transnational Geographies of Islamism, Capitalism and Subjectivity', pp. 23-53.

48. Bilefsky, 'A Fashion Magazine Unshy About Baring a Bit of Piety'.

49. Cihan Tugal cites the story of Yasin as a sample case to show the transformation from 'Milli Görüş' ideas of anti-westernism and anti-capitalism to new politics. See his, Passive Revolution: Absorbing the Islamic Challenge to Capitalism (Stanford, CA: Stanford University Press, 2009), p.72.

50. Özdemir, $M \ddot{U} S \dot{I} A D$, p.76.

51. Interview with Davud Şanver, 12 Aug. 2010.

52. Hamit Y., 22 Dec. 2010.

53. Interview with Alkan.

54. Interview with Yarar.

55. Interview with Șanver.

56. Interview with Halim Ö., 27 Dec. 2010.

57. Interview with Mehmet K., 3 Jan. 2011.

58. Interview with Şanver.

59. Özdemir, $M \ddot{U} S \dot{I} A D$, Introduction.

60. Interview with Şanver.

61. Interview with Orhan Sağlam, 24 Aug. 2010. 